\title{
MECHANISMS IN ENDOCRINOLOGY \\ Exogenous insulin does not increase muscle protein synthesis rate when administered systemically: a systematic review
}

\author{
Jorn Trommelen, Bart B L Groen, Henrike M Hamer, Lisette C P G M de Groot ${ }^{1}$ \\ and Luc J C van Loon \\ Department of Human Movement Sciences, Faculty of Health, Medicine and Life Sciences, NUTRIM School for \\ Nutrition, Toxicology and Metabolism, Maastricht University, PO Box 616, 6200 MD Maastricht, The Netherlands and \\ ${ }^{1}$ Division of Human Nutrition, Wageningen University, Wageningen, The Netherlands
}

\author{
Correspondence \\ should be addressed \\ to L J C van Loon \\ Email \\ I.vanloon@ \\ maastrichtuniversity.nl
}

\begin{abstract}
Background: Though it is well appreciated that insulin plays an important role in the regulation of muscle protein metabolism, there is much discrepancy in the literature on the capacity of exogenous insulin administration to increase muscle protein synthesis rates in vivo in humans.

Objective: To assess whether exogenous insulin administration increases muscle protein synthesis rates in young and older adults.

Design: A systematic review of clinical trials was performed and the presence or absence of an increase in muscle protein synthesis rate was reported for each individual study arm. In a stepwise manner, multiple models were constructed that excluded study arms based on the following conditions: model 1, concurrent hyperaminoacidemia; model 2, insulin-induced hypoaminoacidemia; model 3, supraphysiological insulin concentrations; and model 4, older, more insulin resistant, subjects. Conclusions: From the presented data in the current systematic review, we conclude that: i) exogenous insulin and amino acid administration effectively increase muscle protein synthesis, but this effect is attributed to the hyperaminoacidemia;

ii) exogenous insulin administered systemically induces hypoaminoacidemia which obviates any insulin-stimulatory effect on muscle protein synthesis; iii) exogenous insulin resulting in supraphysiological insulin levels exceeding 50000 pmol/l may effectively augment muscle protein synthesis; iv) exogenous insulin may have a diminished effect on muscle protein synthesis in older adults due to age-related anabolic resistance; and v) exogenous insulin administered systemically does not increase muscle protein synthesis in healthy, young adults.

European Journal of Endocrinology

(2015) 173, R25-R34
\end{abstract}

\section{Introduction}

Aging is associated with a progressive loss of skeletal muscle mass and function, coined sarcopenia (1). Agerelated muscle loss is associated with many adverse health outcomes including increased falls, need for institutionalization, early onset of disabilities, decline in quality of life, increased likelihood of developing chronic metabolic diseases, and increased mortality (2). Owing to the global expansion of the elderly population, sarcopenia is becoming an increasing burden on our healthcare system (3).
(C) 2015 European Society of Endocrinology Printed in Great Britain
The etiology of muscle loss with aging remains far from understood. While multifaceted in nature, the observed decline in muscle mass must stem from a structural imbalance between muscle protein synthesis and breakdown rates. The loss of muscle mass may be attributed to a decrease in muscle protein synthesis, an increase in muscle protein breakdown, or a combination of both. Previous work suggests that post-absorptive muscle protein synthesis rates are not compromised with

Published by Bioscientifica Ltd 
aging (4). Therefore, investigators have shifted their focus to possible age-related blunted responses to anabolic stimuli such as food intake $(1,5,6)$. Several studies have now shown that the postprandial muscle protein synthetic response to a single dose of amino acids is attenuated in senescent muscle, a phenomenon that has been termed 'anabolic resistance' $(1,6)$. One of the potential mechanisms underlying anabolic resistance may include an increase in insulin resistance with aging $(7,8)$.

Insulin is well recognized as a key hormone responsible for increasing endogenous carbohydrate and fat storage. However, its role in protein metabolism is more controversial. In vitro studies have shown that insulin stimulates muscle protein synthesis by direct activation of the translation machinery through the PI3K $\rightarrow$ Akt $\rightarrow$ mTORC1 pathway $(9,10,11,12,13,14,15,16,17,18,19)$. Insulin may also affect protein metabolism in vivo due to its vasoactive properties. The postprandial rise in circulating insulin stimulates endothelial-dependent vasodilation by virtue of its action on endothelial nitric oxide synthase, resulting in greater capillary recruitment, increased microvascular volume, and nutritive blood flow to skeletal muscle tissue (20). It could be speculated that the greater post-prandial perfusion will increase the exposure of muscle tissue to nutrients and growth factors and increase muscle protein synthesis. However, whether insulin has a stimulatory effect on post-prandial muscle protein synthesis in humans has been the subject of much debate $(21,22)$. Many believe that circulating insulin concentrations are simply permissive, as opposed to modulatory, to allow an increase in muscle protein synthesis in healthy young subjects (21). Specifically, only a small amount of insulin is thought to be necessary to 'prime' the system and it is the subsequent increase in amino acid availability that drives the post-prandial muscle protein synthesis response (23). However, it is speculated that older adults are more resistant to the effect of insulin on muscle protein synthesis, a defect associated with endothelial dysfunction $(24,25,26)$. This systematic review examines the existing literature regarding the proposed effect of increasing circulating insulin levels on muscle protein synthesis in vivo in humans and tries to define whether such an effect differs between young and older adults.

\section{Methods}

\section{Search strategy}

A systematic review was performed according to PRISMA guidelines (27). In short, a computerized search of the literature was performed in January 2014 by using the PubMed database (http://www.ncbi.nlm.gov/pubmed/) and by hand searching reference lists of the identified studies and key literature reviews. The following search terms were used: insulin; hyperinsulinism; muscle; leg; forearm; myofibrillar; anabol*; protein synthe* and protein accretion and the Boolean functions AND and OR. The final electronic search was performed on 8th August 2014.

\section{Eligibility criteria}

Types of studies $>$ Clinical trials studying the administration of insulin to healthy humans. Studies were restricted to those written in the English language. No publication date restrictions were imposed.

Types of participants $>$ Healthy human participants of any age receiving exogenous insulin were considered and stratified in healthy young adults (group mean age between 18 and 65 years) or older adults (group mean age $\geq 65$ years). To study the effect of age on insulin-mediated muscle protein synthesis per se, subjects with any apparent co-morbidity, including diabetes, were excluded.

Types of intervention - This review was limited to studies examining exogenous insulin administration.

Types of outcome measures $>$ The primary outcome measure is qualitative assessment of muscle protein synthesis, i.e. a significant increase or no effect. The included studies assessed muscle protein synthesis as measured by precursor rate of disappearance (leg Rd) in the two-pool arteriovenous balance method, intracellular precursor utilization $\left(\mathrm{F}_{\mathrm{o}, \mathrm{m}}\right)$ in the three-pool arteriovenous balance method, or fractional synthetic rate (FSR) in the precursor-product model (28). These measures tended to reach similar qualitative assessments of muscle protein synthesis (data not shown), therefore no distinction between models was made for interpretation of the reported effect of insulin on muscle protein synthesis.

\section{Study selection}

Eligibility assessment was performed individually by two authors (J Trommelen and B B L Groen). Disagreements between reviewers were resolved by consensus. Titles and abstracts identified by the search strategy were screened for relevance, defined by meeting all of the following criteria: i) human subjects, ii) study design was a clinical trial, iii) intervention included exogenous insulin 
administration in at least one of the study arms, iv) assessed mixed muscle protein synthesis $\left(\mathrm{Rd}, \mathrm{F}_{\mathrm{o}, \mathrm{m}}\right.$, or FSR), and v) full-text accessibility.

\section{Data items and collection process}

Two authors (J Trommelen and B B L Groen) extracted data from included studies individually. Disagreements between reviewers were resolved by consensus. Information was extracted from each included trial on: i) subject characteristics, including age and number; ii) muscle protein synthesis assessment model (data not shown); iii) type of intervention, including dose, co-intervention, infusion compartment, and comparator groups; and iv) study outcome, including effect of exogenous insulin on muscle protein synthesis, clustered in significant increase, or no effect.

\section{Data synthesis}

The trials were reviewed with full tabulation of the results of all included studies. Owing to clinical heterogeneity in experimental designs, it was not possible to conduct a meta-analysis. In addition, differences in experimental methods are known to introduce variability in muscle protein synthesis, complicating quantitative analysis between studies (readers are referred to Smith et al. (29) for a review on this topic). Therefore, qualitative assessment of muscle protein synthesis, i.e. a significant increase or no effect, was determined for included studies. From these data, we constructed several models in which study arms were excluded based on (biological) rationale. In model 1 study arms with concurrent hyperaminoacidemia are excluded. Amino acids can independently stimulate muscle protein synthesis as well as endogenous insulin release, making it impossible to distinguish between the effect of insulin and that of the amino acid infusion (30, 31). Model 2 additionally excludes study arms with insulin-mediated hypoaminoacidemia. It has been suggested that the effect of insulin on muscle protein synthesis is mediated by insulin-induced changes in amino acid delivery to the muscle $(8,26,32,33)$. Systemic insulin infusion induces hypoaminoacidemia, which may limit muscle amino acid delivery. Therefore in this model, study arms were excluded that allowed amino acid levels to drop below baseline. Model 3 additionally excludes study arms achieving supraphysiological insulin concentrations. This was done to differentiate between supraphysiological levels that can only be achieved by insulin administration (>1200 pmol/l) and physiological levels within reach of endogenous production in response to a mixed meal ( $\leq 1200 \mathrm{pmol} / \mathrm{l})$. Model 4 additionally excludes study arms in older subjects, because it has been suggested that elderly are more resistant to the proposed stimulatory properties of insulin on muscle protein synthesis $(24,26)$.

\section{Results}

\section{Study selection}

The search of the PubMed database provided a total of 2021 citations (see Fig. 1). From the total of 2025 citations, 1980 studies were discarded, because after reviewing the abstracts these papers did not meet the inclusion criteria. The full text of the remaining 45 citations was examined in more detail. After careful reading of the full text, an additional ten studies did not meet the inclusion criteria as described. A total of 40 studies met the eligibility criteria and were included in the systematic review.

\section{Study characteristics}

All selected studies are summarized in Table 1.

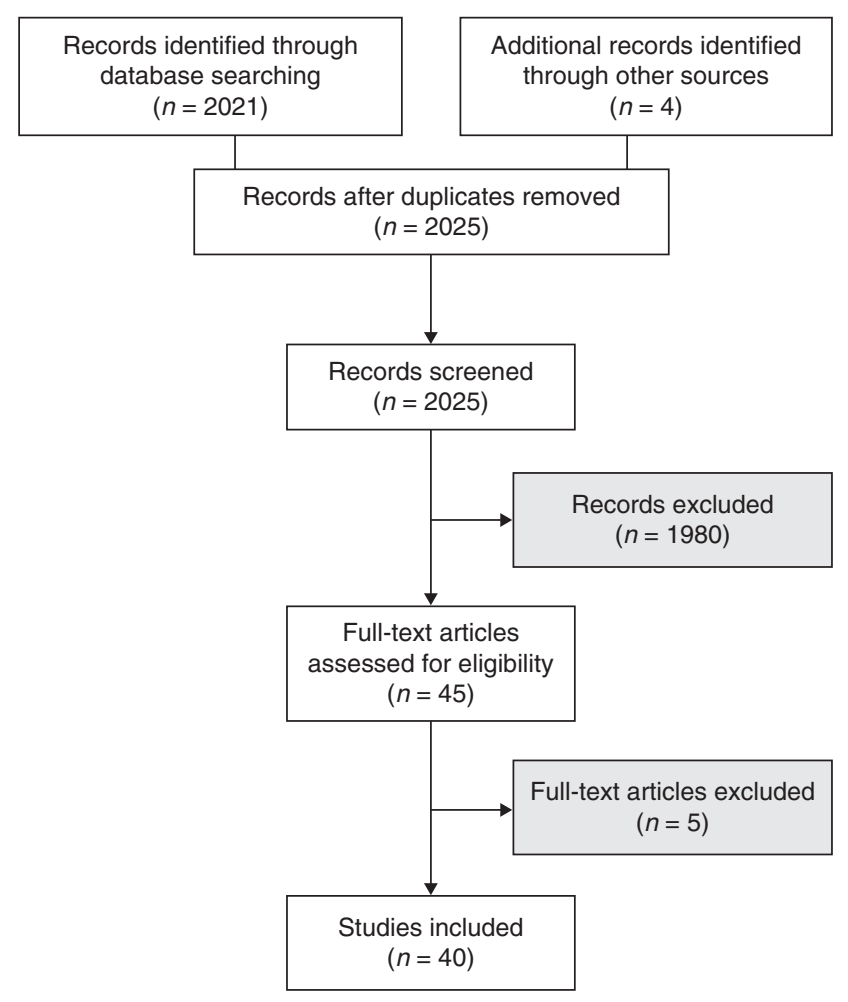

Figure 1

Flow diagram of study identification. 


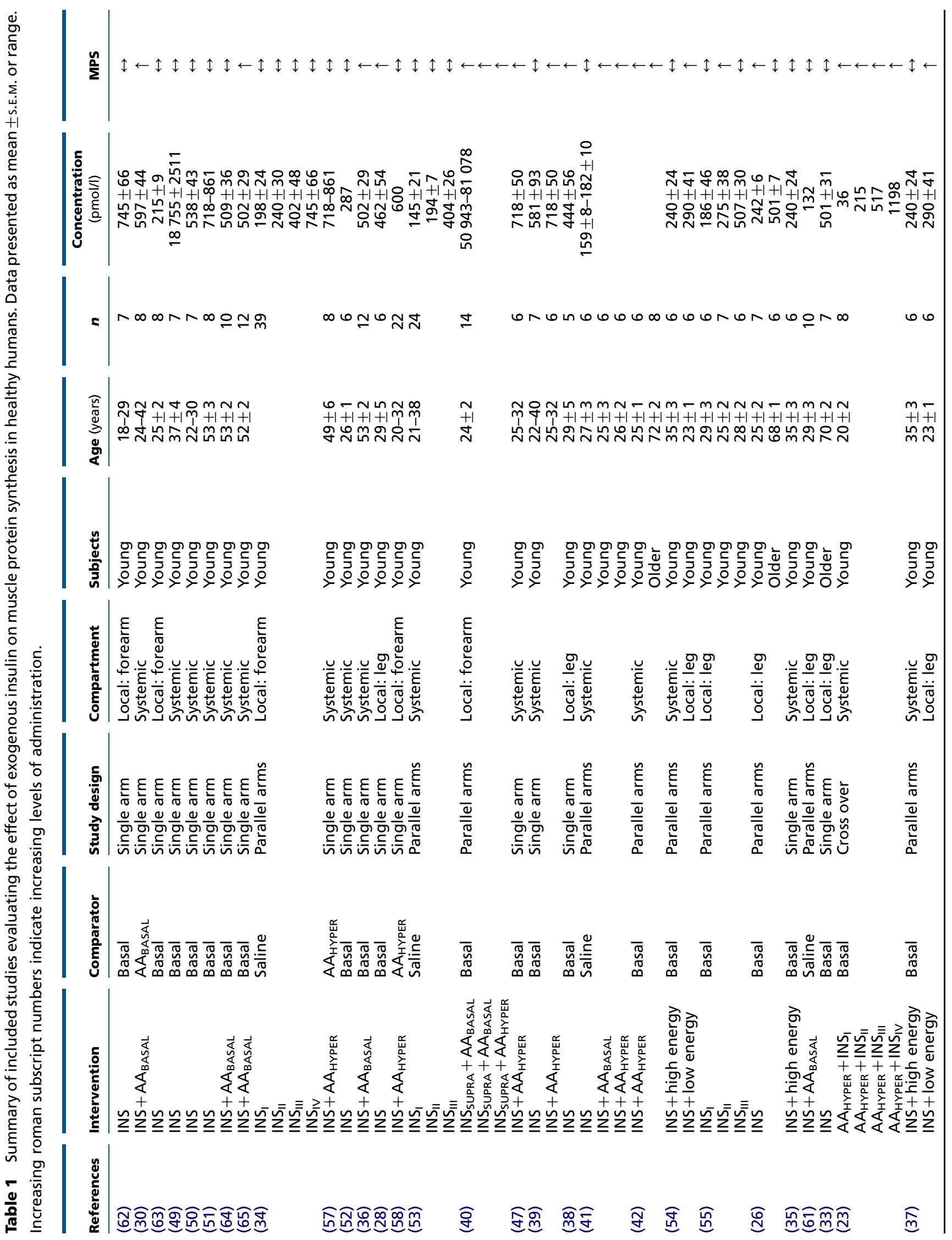




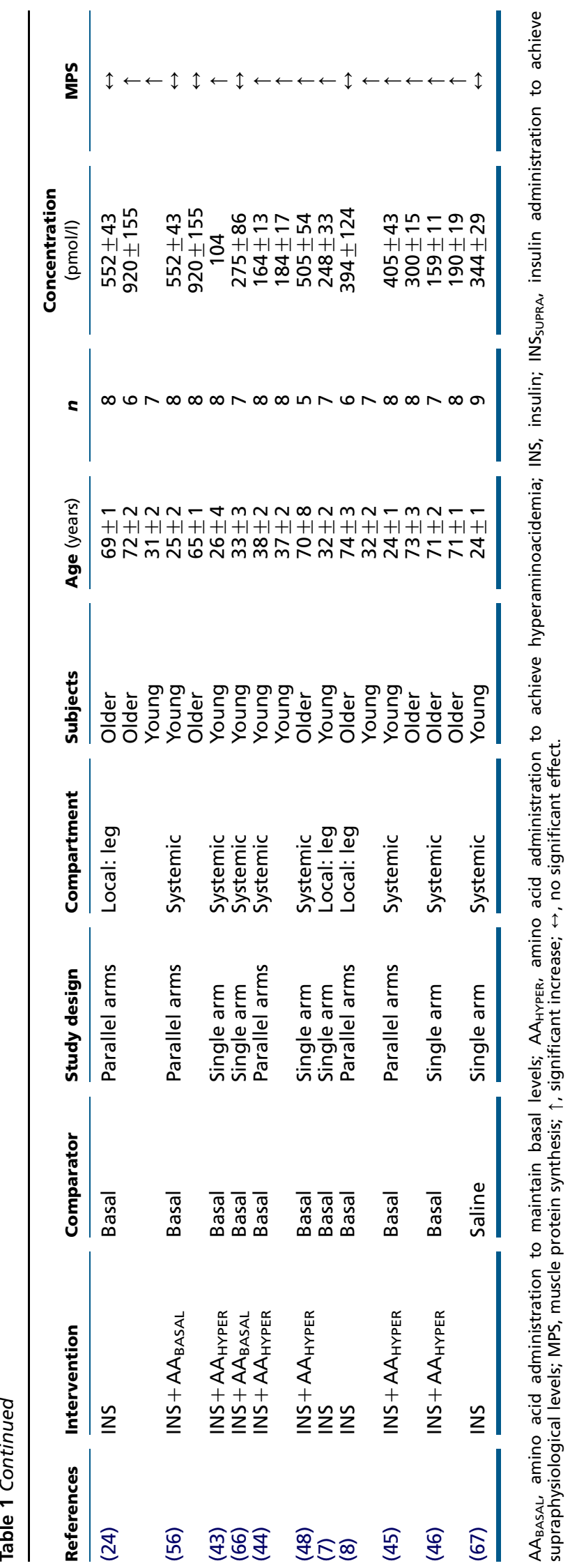

Methods $>$ A high heterogeneity in methodology was observed. Study designs included single-arm, parallelarms, and crossover studies. Comparator groups varied considerably, including no intervention (basal conditions), saline, alternative insulin dosages, or amino acid administration protocols.

Participants - The main eligibility criteria entailed good health. Most studies reported preliminary medical history examination and standard blood tests (mainly for glucose tolerance assessment).

Interventions - The exogenous insulin dosages that were applied resulted in plasma insulin concentrations that ranged from fasting ( $36 \mathrm{pmol} / \mathrm{l})$ to supraphysiological (81 078 pmol/l) levels. Both systemic and local infusion protocols were commonly used. Local insulin infusion protocols used either the forearm or leg as compartment. Co-intervention varied considerably; most common was co-infusion of amino acids.

\section{Data synthesis}

A total of 40 studies were identified for inclusion in the review, varying considerably in the experimental design. Numerous studies applied research designs that included multiple experimental arms with separate interventions and many of which reported opposing findings, making it difficult to draw conclusions on a study level. In addition, several of the identified studies included co-interventions, such as drug administration or exercise protocols, which will influence the results. Therefore, data synthesis was performed on a study arm level (see Table 1).

From the 40 selected studies, after exclusion of nonmixed meal-related intervention (i.e., coadministration of pharmaceuticals), a total of 66 study arms were identified that included insulin treatment. From these 66 study arms, 34 found an insulin-stimulatory effect on muscle protein synthesis, while 32 did not find such an effect (see Fig. 2). Twelve study arms consisted of data reused from other included trials $(8,24,34,35,36,37,38$, 39). After deduplication, a total of 54 unique study arms where found, of which 28 reported increased muscle protein synthesis rates, whereas 26 did not.

From these data, we constructed several models that excluded study arms based on (biological) rationale as described earlier. In model 1, study arms were excluded in which the insulin administration was combined with amino acid co-interventions that raised plasma amino acid above basal levels and did not have a comparator group to correct for the increase in plasma amino acids 


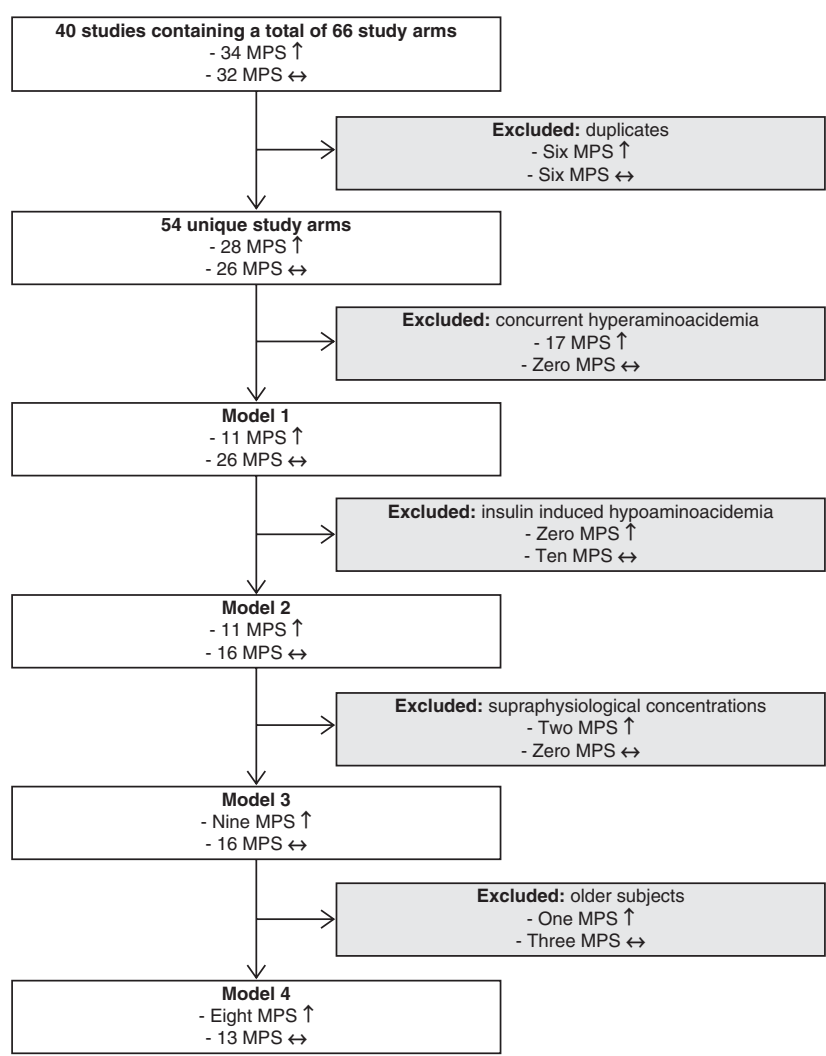

Figure 2

Flow diagram of stepwise models that report the presence or absence of an increase in muscle protein synthesis in response to exogenous insulin. MPS, muscle protein synthesis; $\uparrow$, significant increase; $\leftrightarrow$, no significant effect.

$(23,40,41,42,43,44,45,46,47,48)$. This criterion excluded 17 study arms, all of which reported increased muscle protein synthesis.

Model 2 additionally excluded study arms in which amino acid levels were allowed to drop below basal levels $(41,49,50,51,52,53,54,55)$. This criterion excluded an additional ten study arms compared with model 1 , none of which reported an effect on muscle protein synthesis.

Model 3 additionally excluded study arms in which a supraphysiological concentration of insulin was achieved (40). This criterion excluded an additional two study arms compared with model 2 , which both reported that insulin increases muscle protein synthesis.

Model 4 additionally excluded study arms in older subjects $(8,24,26,33,56)$. This criterion excluded an additional four interventions compared with model 3 , one of which reported an insulin-stimulatory effect of on muscle protein synthesis, whereas the other three did not. After these final exclusions, model 4 included a total of
21 study arms, eight of which reported an increase in muscle protein synthesis, whereas 13 did not.

\section{Discussion}

This systematic review examined the literature regarding the proposed age-related effect of exogenous insulin administration on muscle protein synthesis rates in vivo in humans. Though ample studies have been performed to assess the impact of exogenous insulin administration on muscle protein synthesis, data do not support a stimulatory role of exogenous insulin administration on muscle protein synthesis rates in vivo in humans.

Amino acids are well recognized for their independent capacity to stimulate muscle protein synthesis $(30,31)$. Therefore, insulin plus amino acid administration has consistently been shown to increase muscle protein synthesis $(23,40,41,42,43,44,45,46,47,48)$. Without an adequate control group with a similar degree of hyperaminoacidemia, it is impossible to differentiate between the proposed anabolic properties of insulin vs amino acid administration. As expected, all 17 study arms combining both insulin and amino acid administration excluded from the analyses by this criterium reported an increase in muscle protein synthesis (see model 1 in Fig. 2). It should be noted that a state of concurrent hyperinsulinemia and hyperaminoacidemia reflects the physiological conditions following ingestion of a mixed meal. Three studies investigated whether exogenous insulin administration can further augment muscle protein synthesis during hyperaminoacidemic conditions, and all of them failed to detect an incremental effect $(23,57,58)$. These results suggest that concurrent hyperinsulinemia and hyperaminoacidemia increase muscle protein synthesis but, at least in healthy young subjects, this effect seems entirely attributed to the hyperaminoacidemia.

I.v. insulin administration is followed by a dosedependent reduction in circulating plasma amino acid levels, with the branched chain amino acids being most sensitive to the increase in circulating insulin levels (59). This insulin-induced hypoaminoacidemia is a reflection of increased amino acid uptake from the plasma in combination with the proposed inhibitory action of increasing insulin levels on endogenous proteolysis $(50,60)$. It has been suggested that the proposed positive effect of exogenous insulin administration on muscle protein synthesis is mediated by insulin-induced increase in blood flow and subsequent greater amino acid delivery to the muscle. A decline in circulating amino acid concentrations may limit amino acid delivery to the 
muscle and consequently restrict the capacity of insulin to stimulate muscle protein synthesis. To prevent such a decline in amino acid levels, several studies have applied i.v. amino acid infusions in combination with insulin administration or infused exogenous insulin locally in the femoral or brachial artery. In model 2, ten study arms that showed insulin-induced hypoaminoacidemia were excluded. None of these ten study arms found an insulinstimulatory effect of insulin on muscle protein synthesis, supporting the rational that insulin-induced hypoaminoacidemia may obviate the proposed stimulating properties of insulin administration on amino acid delivery to the muscle and subsequent increase in muscle protein synthesis.

Insulin has been shown to augment muscle protein synthesis in vitro $(9,10,11,12,13,14,15,16,17,19)$. However, from in vivo human studies there is much discrepancy on the proposed positive effects of exogenous insulin on muscle protein synthesis rates. It has been suggested that the apparent discrepancy is attributed to the more than tenfold higher supraphysiological insulin concentrations (14000 pmol/l or above) that are applied in the in vitro models when compared with the more physiological increases in plasma insulin levels (up to 1200 pmol/l) applied within most in vivo human studies $(23,40)$. One study administered exogenous insulin locally in the forearm to achieve local supraphysiological insulin levels exceeding $50000 \mathrm{pmol} / \mathrm{l}$, while clamping amino acids at basal arterial or venous levels, and reported an increase in muscle protein synthesis rates (40). Their results suggest that supraphysiological insulin levels may effectively stimulate muscle protein synthesis.

It has been postulated that the elderly are more resistant to anabolic stimuli, such as increases in circulating plasma insulin and amino acids concentrations, when compared with younger adults $(1,26)$. Anabolic resistance to amino acid and/or insulin administration in the older population could be attributed to impairments in insulinstimulated amino acid delivery to the muscle (24). As a consequence, we speculated that exogenous insulin administration may augment muscle protein synthesis in older (more insulin resistant) adults. After stratifying the data in young and older adults, we identified one study that reported a positive effect of exogenous insulin administration on muscle protein synthesis in older subjects (24), whereas three study arms failed to observe such an effect $(8,24,26,33,56)$. Interestingly, the insulinstimulated increase in muscle protein synthesis in the older subjects was observed only under relatively high local insulin levels exceeding $900 \mathrm{pmol} / \mathrm{l}$ (24). Lower dosages of local insulin administration, resulting in local plasma insulin levels of $\sim 500 \mathrm{pmol}$, did not seem to augment muscle protein synthesis in the older adults. These data suggest that older adults may be more resistant to the anabolic properties of insulin, a resistance that could be overcome at higher insulin concentrations.

We applied strict exclusion criteria in model 4 to exclude factors that may modulate the proposed stimulatory effect of exogenous insulin administration in healthy adults, including i) concurrent hyperaminoaminoacidemia, ii) insulin-induced hypoaminoacidemia, iii) supraphysiological insulin concentrations, and iv) older, more insulin resistant, subjects. We identified eight study arms that reported an insulin-stimulated increase in muscle protein synthesis, whereas 14 study arms failed to observe an insulin-stimulated increase in muscle protein synthesis rates in healthy young subjects. A subgroup of model 4 includes eight study arms in which insulin is locally infused into the leg, of which five study arms reported an increase in muscle protein synthesis rate, whereas three did not. Three of these study arms come from a dose-response study, in which both a low dose $(0.05 \mathrm{mU} / \mathrm{min} \times 100 \mathrm{ml}$ of leg) and high dose $(0.30 \mathrm{mU} / \mathrm{min} \times 100 \mathrm{ml}$ of leg) of insulin administration did not increase muscle protein synthesis rates, whereas the intermediate dose $(0.15 \mathrm{mU} / \mathrm{min} \times 100 \mathrm{ml}$ of leg $)$ did (55). This intermediate dose increased muscle protein synthesis rates in all five study arms it was applied in $(7,24,28,54,55)$, whereas no increases in muscle protein synthesis rates were observed in the three study arms applying alternate dosing $(55,61)$. This suggests a U-shaped dose-response effect of exogenous insulin administration on muscle protein synthesis where a dose of $\sim 0.15 \mathrm{mU} / \mathrm{min} \times 100 \mathrm{ml}$ of leg may stimulate muscle protein synthesis. Interestingly, exogenous insulin administration does not seem to stimulate muscle protein synthesis when infused locally in the forearm. In this subgroup of model 4, all six interventions reported no increase in muscle protein synthesis rates, despite a wide range of investigated dosing protocols $(34,58,62,63)$. In an attempt to further delineate the results, the data were reviewed for other potential modulating factors. The presence or absence of a stimulating effect in these studies could not be attributed to differences in levels of circulating insulin or the choice of amino acid tracers (data not shown).

In all of the presented work, exogenous insulin has been administered in a clamp-based approach. This approach may have its limitations as it could be speculated that the steep postprandial rise in circulating insulin level 
serves a regulatory function to activate various physiological processes that facilitate the post-prandial increase in muscle protein synthesis rate. Such temporal changes in insulin secretion, amino acid delivery and uptake, and intramyocellular signaling must be tightly regulated to support the post-prandial anabolic response. Furthermore, we should note that there may be differences in the relevance of circulating insulin levels on modulating the synthesis of various (sets of) proteins in skeletal muscle tissue (60).

From the presented data in the current systematic review, we conclude that: i) exogenous insulin and amino acid administration effectively increase muscle protein synthesis; however, this effect is attributed to the hyperaminoacidemia; ii) exogenous insulin administered systemically induces hypoaminoacidemia, which obviates any insulin-stimulatory effect on muscle protein synthesis; iii) exogenous insulin resulting in supraphysiological insulin levels exceeding $50000 \mathrm{pmol} / 1$ may effectively stimulate muscle protein synthesis; iv) exogenous insulin may have a diminished effect of muscle protein synthesis in older adults due to age-related anabolic resistance; and $\mathrm{v}$ ) exogenous insulin administered systemically does not increase muscle protein synthesis in healthy, young adults. Based on the existing literature, we conclude that exogenous insulin administration does not increase muscle protein synthesis rates in healthy, young, or older adults.

\section{Declaration of interest}

The authors declare that there is no conflict of interest that could be perceived as prejudicing the impartiality of the review.

\section{Funding}

This review did not receive any specific grant from any funding agency in the public, commercial or not-for-profit sector.

\section{Author contribution statement}

J Trommelen wrote the manuscript, developed research strategy, and extracted data; B B L Groen extracted data and made manuscript revisions; and H M Hamer, L C P G M de Groot, and L J C van Loon made manuscript revisions.

\section{References}

1 Cuthbertson D, Smith K, Babraj J, Leese G, Waddell T, Atherton P, Wackerhage H, Taylor PM \& Rennie MJ. Anabolic signaling deficits underlie amino acid resistance of wasting, aging muscle. FASEB Journal 200519 422-424. (doi:10.1096/fj.04-2640fje)
2 Abellan Van Kan G. Epidemiology and consequences of sarcopenia. Journal of Nutrition, Health \& Aging 200913 708-712. (doi:10.1007/ s12603-009-0201-z)

3 Kinsella K \& He W. An aging world: 2008. In International Population Reports, pp P95/09-91. U.S. Department of Health and Human Services, 2009. http://www.census.gov/prod/2009pubs/p95-09-1.pdf

4 Volpi E, Sheffield-Moore M, Rasmussen BB \& Wolfe RR. Basal muscle amino acid kinetics and protein synthesis in healthy young and older men. Journal of the American Medical Association 20012861206. (doi:10.1001/jama.286.10.1206)

5 Koopman R \& van Loon LJC. Aging, exercise, and muscle protein metabolism. Journal of Applied Physiology 2009106 2040. (doi:10.1152/ japplphysiol.91551.2008)

6 Katsanos CS, Kobayashi H, Sheffield-Moore M, Aarsland A \& Wolfe RR. Aging is associated with diminished accretion of muscle proteins after the ingestion of a small bolus of essential amino acids. American Journal of Clinical Nutrition 200582 1065-1073.

7 Timmerman KL, Lee JL, Dreyer HC, Dhanani S, Glynn EL, Fry CS, Drummond MJ, Sheffield-Moore M, Rasmussen BB \& Volpi E. Insulin stimulates human skeletal muscle protein synthesis via an indirect mechanism involving endothelial-dependent vasodilation and mammalian target of rapamycin complex 1 signaling. Journal of Clinical Endocrinology and Metabolism 201095 3848-3857. (doi:10.1210/jc. 2009-2696)

8 Timmerman KL, Lee JL, Fujita S, Dhanani S, Dreyer HC, Fry CS, Drummond MJ, Sheffield-Moore M, Rasmussen BB \& Volpi E. Pharmacological vasodilation improves insulin-stimulated muscle protein anabolism but not glucose utilization in older adults. Diabetes 201059 2764-2771. (doi:10.2337/db10-0415)

9 Frayn $\mathrm{KN} \&$ Maycock PF. Regulation of protein metabolism by a physiological concentration of insulin in mouse soleus and extensor digitorum longus muscles. Effects of starvation and scald injury. Biochemical Journal 1979184323.

10 Fulks RM, Li JB \& Goldberg AL. Effects of insulin, glucose, and amino acids on protein turnover in rat diaphragm. Journal of Biological Chemistry $1975250290-298$.

11 Jefferson L, Rannels D, Munger B \& Morgan H. Insulin in the regulation of protein turnover in heart and skeletal muscle. Federation Proceedings 197433 1098-1104.

12 Jefferson L, Li J \& Rannels S. Regulation by insulin of amino acid release and protein turnover in the perfused rat hemicorpus. Journal of Biological Chemistry 19772521476.

13 Li J, Higgins J \& Jefferson L. Changes in protein turnover in skeletal muscle in response to fasting. American Journal of Physiology. Endocrinology and Metabolism 1979236 E222.

14 Lundholm K, Edström S, Ekman L, Karlberg I, Walker P \& Schersten T. Protein degradation in human skeletal muscle tissue: the effect of insulin, leucine, amino acids and ions. Clinical Science 198160319.

15 Jefferson LS. Lilly Lecture 1979: role of insulin in the regulation of protein synthesis. Diabetes 198029 487. (doi:10.2337/diab.29.6.487)

16 Jefferson L, Koehler J \& Morgan H. Effect of insulin on protein synthesis in skeletal muscle of an isolated perfused preparation of rat hemicorpus. PNAS 197269 816. (doi:10.1073/pnas.69.4.816)

17 Stirewalt WS, Low R \& Slaiby JM. Insulin sensitivity and responsiveness of epitrochlearis and soleus muscles from fed and starved rats. Recognition of differential changes in insulin sensitivities of protein synthesis and glucose incorporation into glycogen. Biochemical Journal 1985227355.

18 Proud CG \& Denton RM. Molecular mechanisms for the control of translation by insulin. Biochemical Journal 1997328329.

19 Kimball SR, Vary TC \& Jefferson LS. Regulation of protein synthesis by insulin. Annual Review of Physiology 199456 321-348. (doi:10.1146/ annurev.ph.56.030194.001541)

20 Muniyappa R, Montagnani M, Koh KK \& Quon MJ. Cardiovascular actions of insulin. Endocrine Reviews 200728 463-491. (doi:10.1210/ er.2007-0006) 
21 Phillips SM. Insulin and muscle protein turnover in humans: stimulatory, permissive, inhibitory, or all of the above? American Journal of Physiology. Endocrinology and Metabolism 2008295 E731. (doi:10.1152/ajpendo.90569.2008)

22 Timmerman KL \& Volpi E. Amino acid metabolism and regulatory effects in aging. Current Opinion in Clinical Nutrition and Metabolic Care 200811 45. (doi:10.1097/MCO.0b013e3282f2a592)

23 Greenhaff PL, Karagounis L, Peirce N, Simpson EJ, Hazell M, Layfield R, Wackerhage H, Smith K, Atherton P \& Selby A. Disassociation between the effects of amino acids and insulin on signaling, ubiquitin ligases, and protein turnover in human muscle. American Journal of Physiology. Endocrinology and Metabolism 2008295 E595-E604. (doi:10.1152/ ajpendo.90411.2008)

24 Fujita S, Glynn EL, Timmerman KL, Rasmussen BB \& Volpi E. Supraphysiological hyperinsulinaemia is necessary to stimulate skeletal muscle protein anabolism in older adults: evidence of a true age-related insulin resistance of muscle protein metabolism. Diabetologia 200952 1889-1898. (doi:10.1007/s00125-009-1430-8)

25 Meneilly G, Elliot T, Bryer-Ash M \& Floras J. Insulin-mediated increase in blood flow is impaired in the elderly. Journal of Clinical Endocrinology and Metabolism 1995801899.

26 Rasmussen BB, Fujita S, Wolfe RR, Mittendorfer B, Roy M, Rowe VL \& Volpi E. Insulin resistance of muscle protein metabolism in aging. FASEB Journal 200620 768-769. (doi:10.1096/fj.05-4607fje)

27 Moher D, Liberati A, Tetzlaff J \& Altman DG. Preferred reporting items for systematic reviews and meta-analyses: the PRISMA statement. PLoS Medicine 20096 e1000097. (doi:10.1371/journal.pmed.1000097)

28 Biolo G, Declan Fleming RY \& Wolfe RR. Physiologic hyperinsulinemia stimulates protein synthesis and enhances transport of selected amino acids in human skeletal muscle. Journal of Clinical Investigation 199595 811-819. (doi:10.1172/JCI117731)

29 Smith GI, Patterson BW \& Mittendorfer B. Human muscle protein turnover - why is it so variable? Journal of Applied Physiology 2011110 480-491. (doi:10.1152/japplphysiol.00125.2010)

30 Bennet W, Connacher A, Scrimgeour C, Smith K \& Rennie M. Increase in anterior tibialis muscle protein synthesis in healthy man during mixed amino acid infusion: studies of incorporation of $\left[1-{ }^{13} \mathrm{C}\right]$ leucine. Clinical Science 198976447.

31 Kimball S. The role of nutrition in stimulating muscle protein accretion at the molecular level. Biochemical Society Transactions $2007 \mathbf{3 5}$ 1298-1301. (doi:10.1042/BST0351298)

32 DeSouza CA, Shapiro LF, Clevenger CM, Dinenno FA, Monahan KD, Tanaka H \& Seals DR. Regular aerobic exercise prevents and restores age-related declines in endothelium-dependent vasodilation in healthy men. Circulation 2000102 1351-1357. (doi:10.1161/01.CIR.102. 12.1351)

33 Fujita S, Rasmussen BB, Cadenas JG, Drummond MJ, Glynn EL, Sattler FR \& Volpi E. Aerobic exercise overcomes the age-related insulin resistance of muscle protein metabolism by improving endothelial function and Akt/mammalian target of rapamycin signaling. Diabetes 200756 1615-1622. (doi:10.2337/db06-1566)

34 Louard RJ, Fryburg DA, Gelfand RA \& Barrett EJ. Insulin sensitivity of protein and glucose metabolism in human forearm skeletal muscle. Journal of Clinical Investigation 199290 2348-2354. (doi:10.1172/ JCI116124)

35 Bell JA, Volpi E, Fujita S, Cadenas JG, Sheffield-Moore M \& Rasmussen BB. Skeletal muscle protein anabolic response to increased energy and insulin is preserved in poorly controlled type 2 diabetes. Journal of Nutrition 2006136 1249-1255.

36 Newman E, Heslin MJ, Wolf RF, Pisters PW \& Brennan MF. The effect of systemic hyperinsulinemia with concomitant amino acid infusion on skeletal muscle protein turnover in the human forearm. Metabolism 199443 70-78. (doi:10.1016/0026-0495(94)90159-7)

37 Drummond MJ, Bell JA, Fujita S, Dreyer HC, Glynn EL, Volpi E \& Rasmussen BB. Amino acids are necessary for the insulin-induced activation of mTOR/S6K1 signaling and protein synthesis in healthy and insulin resistant human skeletal muscle. Clinical Nutrition $2008 \mathbf{2 7}$ 447-456. (doi:10.1016/j.clnu.2008.01.012)

38 Biolo G, Williams BD, Fleming R \& Wolfe R. Insulin action on muscle protein kinetics and amino acid transport during recovery after resistance exercise. Diabetes 199948 949-957. (doi:10.2337/diabetes. 48.5.949)

39 Zanetti M, Barazzoni R, Kiwanuka E \& Tessari P. Effects of branchedchain-enriched amino acids and insulin on forearm leucine kinetics. Clinical Science 199997 437-448. (doi:10.1042/CS19990163)

40 Hillier TA, Fryburg DA, Jahn LA \& Barrett EJ. Extreme hyperinsulinemia unmasks insulin's effect to stimulate protein synthesis in the human forearm. American Journal of Physiology 1998274 E1067-E1074.

41 Nygren J \& Nair KS. Differential regulation of protein dynamics in splanchnic and skeletal muscle beds by insulin and amino acids in healthy human subjects. Diabetes 200352 1377-1385. (doi:10.2337/ diabetes.52.6.1377)

42 Guillet C, Prod'homme M, Balage M, Gachon P, Giraudet C, Morin L, Grizard J \& Boirie Y. Impaired anabolic response of muscle protein synthesis is associated with S6K1 dysregulation in elderly humans. FASEB Journal 200418 1586-1587.

43 Guillet C, Delcourt I, Rance M, Giraudet C, Walrand S, Bedu M, Duche P $\&$ Boirie Y. Changes in basal and insulin and amino acid response of whole body and skeletal muscle proteins in obese men. Journal of Clinical Endocrinology and Metabolism 200994 3044-3050. (doi:10.1210/ jc.2008-2216)

44 Smith GI, Atherton P, Reeds DN, Mohammed BS, Jaffery H, Rankin D, Rennie MJ \& Mittendorfer B. No major sex differences in muscle protein synthesis rates in the postabsorptive state and during hyperinsulinemia-hyperaminoacidemia in middle-aged adults. Journal of Applied Physiology 2009107 1308-1315. (doi:10.1152/japplphysiol.00348. 2009)

45 Chevalier S, Goulet ED, Burgos SA, Wykes LJ \& Morais JA. Protein anabolic responses to a fed steady state in healthy aging. Journals of Gerontology. Series A, Biological Sciences and Medical Sciences 2011 66A 681-688. (doi:10.1093/gerona/glr036)

46 Smith GI, Atherton P, Reeds DN, Mohammed BS, Rankin D, Rennie MJ \& Mittendorfer B. Dietary omega-3 fatty acid supplementation increases the rate of muscle protein synthesis in older adults: a randomized controlled trial. American Journal of Clinical Nutrition 2011 93 402-412. (doi:10.3945/ajcn.110.005611)

47 Tessari P, Barazzoni R \& Zanetti M. Differences in estimates of forearm protein synthesis between leucine and phenylalanine tracers following unbalanced amino acid infusion. Metabolism 199948 1564-1569. (doi:10.1016/S0026-0495(99)90246-9)

48 Toth MJ, LeWinter MM, Ades PA \& Matthews DE. Impaired muscle protein anabolic response to insulin and amino acids in heart failure patients: relationship to markers of immune activation. Clinical Science 2010119 467. (doi:10.1042/CS20100110)

49 Denne SC, Liechty EA, Liu YM, Brechtel G \& Baron AD. Proteolysis in skeletal muscle and whole body in response to euglycemic hyperinsulinemia in normal adults. American Journal of Physiology. Endocrinology and Metabolism 1991261 E809-E814.

50 Tessari P, Inchiostro S, Biolo G, Vincenti E \& Sabadin L. Effects of acute systemic hyperinsulinemia on forearm muscle proteolysis in healthy man. Journal of Clinical Investigation 199188 27-33. (doi:10.1172/ JCI115287)

51 Arfvidsson B, Zachrisson H, Moller-Loswick AC, Hyltander A, Sandstrom R \& Lundholm K. Effect of systemic hyperinsulinemia on amino acid flux across human legs in postabsorptive state. American Journal of Physiology. Endocrinology and Metabolism 1991260 E46-E52.

52 McNurlan MA, Essen P, Thorell A, Calder AG, Anderson SE, Ljungqvist O, Sandgren A, Grant I, Tjader I, Ballmer PE et al. Response of protein synthesis in human skeletal muscle to insulin: an investigation with L-[2H5]phenylalanine. American Journal of Physiology 1994267 E102-E108. 
53 Meek SE, Persson M, Ford GC \& Nair KS. Differential regulation of amino acid exchange and protein dynamics across splanchnic and skeletal muscle beds by insulin in healthy human subjects. Diabetes 199847 1824-1835. (doi:10.2337/diabetes.47.12.1824)

54 Bell JA, Fujita S, Volpi E, Cadenas JG \& Rasmussen BB. Short-term insulin and nutritional energy provision do not stimulate muscle protein synthesis if blood amino acid availability decreases. American Journal of Physiology. Endocrinology and Metabolism 2005289 E999-E1006. (doi:10.1152/ajpendo.00170.2005)

55 Fujita S, Rasmussen BB, Cadenas JG, Grady JJ \& Volpi E. Effect of insulin on human skeletal muscle protein synthesis is modulated by insulininduced changes in muscle blood flow and amino acid availability. American Journal of Physiology. Endocrinology and Metabolism 2006291 E745-E754. (doi:10.1152/ajpendo.00271.2005)

56 Wilkes EA, Selby AL, Atherton PJ, Patel R, Rankin D, Smith K \& Rennie MJ. Blunting of insulin inhibition of proteolysis in legs of older subjects may contribute to age-related sarcopenia. American Journal of Clinical Nutrition 200990 1343-1350. (doi:10.3945/ajcn. 2009.27543)

57 Moller-Loswick AC, Zachrisson H, Hyltander A, Korner U, Matthews DE \& Lundholm K. Insulin selectively attenuates breakdown of nonmyofibrillar proteins in peripheral tissues of normal men. American Journal of Physiology. Endocrinology and Metabolism 1994266 E645-E652.

58 Fryburg DA, Jahn LA, Hill SA, Oliveras DM \& Barrett EJ. Insulin and insulin-like growth factor-I enhance human skeletal muscle protein anabolism during hyperaminoacidemia by different mechanisms. Journal of Clinical Investigation 199596 1722-1729. (doi:10.1172/ JCI118217)

59 Fukagawa N, Minaker K, Young V \& Rowe J. Insulin dose-dependent reductions in plasma amino acids in man. American Journal of Physiology. Endocrinology and Metabolism 1986250 E13-E17.
60 Boirie Y, Short KR, Ahlman B, Charlton M \& Nair KS. Tissue-specific regulation of mitochondrial and cytoplasmic protein synthesis rates by insulin. Diabetes 200150 2652. (doi:10.2337/diabetes.50.12.2652)

61 Chow LS, Albright RC, Bigelow ML, Toffolo G, Cobelli C \& Nair KS. Mechanism of insulin's anabolic effect on muscle: measurements of muscle protein synthesis and breakdown using aminoacyl-tRNA and other surrogate measures. American Journal of Physiology. Endocrinology and Metabolism 2006291 E729-E736. (doi:10.1152/ajpendo.00003.2006)

62 Gelfand RA \& Barrett EJ. Effect of physiologic hyperinsulinemia on skeletal muscle protein synthesis and breakdown in man. Journal of Clinical Investigation 198780 1. (doi:10.1172/JCI113033)

63 Fryburg DA, Barrett EJ, Louard RJ \& Gelfand RA. Effect of starvation on human muscle protein metabolism and its response to insulin. American Journal of Physiology. Endocrinology and Metabolism 1990259 E477-E482.

64 Heslin MJ, Newman E, Wolf RF, Pisters PW \& Brennan MF. Effect of hyperinsulinemia on whole body and skeletal muscle leucine carbon kinetics in humans. American Journal of Physiology 1992262 E911-E918.

65 Newman E, Heslin MJ, Wolf RF, Pisters PW \& Brennan MF. The effect of insulin on glucose and protein metabolism in the forearm of cancer patients. Surgical Oncology 19921 257-267. (doi:10.1016/09607404(92)90086-Z)

66 Short KR, Bigelow ML \& Nair KS. Short-term prednisone use antagonizes insulin's anabolic effect on muscle protein and glucose metabolism in young healthy people. American Journal of Physiology. Endocrinology and Metabolism 2009297 E1260-E1268. (doi:10.1152/ ajpendo.00345.2009)

67 Barazzoni R, Short KR, Asmann Y, Coenen-Schimke JM, Robinson MM $\&$ Nair KS. Insulin fails to enhance mTOR phosphorylation, mitochondrial protein synthesis, and ATP production in human skeletal muscle without amino acid replacement. American Journal of Physiology. Endocrinology and Metabolism 2012303 E1117-E1125. (doi:10.1152/ ajpendo.00067.2012)

Received 21 October 2014

Revised version received 24 December 2014

Accepted 2 February 2015 